\title{
AUTENTICITET OG FIKTIONALITET I JUNOT DÍAZ' THE BRIEF WONDROUS LIFE OF OSCAR WAO
}

\begin{abstract}
AUTHENTICITY AND FICTIONALITY | Traditionally literature on historical traumas such as genocide, war and dictatorship has shown careful respect for the extraordinary and tragic nature of the events in question by representing them in soberly realistic, silent or hermetic forms and in authentic testimonies expressing a general sensitivity to the ethical implications of colourful and enjoyable aesthetics. Recently, though, art and literature on memory and history seems to leave behind testimony and the careful performance of silence exploring instead hybrid forms, interaction with visual media, vibrant language and perspectives other than those of the witness and the victim. Junot Díaz' novel The Brief Wondrous Life of Oscar Wao (2007) is one example. The hypothesis explored in this article is that Díaz' loud and colourful book uses fictionality to counter the silence and oppression of death and dictatorship that is also carefully explored.

I argue that the excessive use of "genre" references and magical events explores the limits of authentic representation of historical trauma suggesting instead a reading strategy in which history can be approached emotionally and critically through the explicit use of fictionality.
\end{abstract}

KEYWORDS | Authenticity, fictionality, Junot Díaz, The Brief Wondrous Life of Oscar Wao, Cultural memory, representation

Det interdisciplinære forskningsfelt i Cultural Memory Studies har traditionelt taget sit udgangspunkt i traumatiske erindringer og erindringspolitik i kølvandet på folkemord, krige og diktaturer. En traditionel respons til disse problemstillinger i kunstnerisk produktion har været en respekt for begivenhedernes ekstraordinære og ubegribelige karakter, der kommer til udtryk i sober realisme, autentiske vidneskildringer, tavse eller hermetiske fremstillinger og uvilje mod æstetisering kanoniseret på baggrund af Adornos omdiskuterede kommentar om, at digtning efter Auschwitz er barbarisk (se for eksempel Langer 76-77). Nyere tendenser inden for erindringskunst og -litteratur lægger så småt afstand til den privilegering af vidnesbyrdet, der har været dominerende mod slutningen af det 20. århundrede og benytter sig i stedet af hybride former, friere brug af æstetiske greb og nye medier og inddragelse af perspektiver, der går ud over vidnets og offerets privilegerede epistemiske position. Forbryderens side ses for eksempel fremstillet, dokumenter og fotografier inddrages i værkerne, hyperfiktive romaner, tegneserie- og -filmmedier 
afprøves, og traditionelle skel mellem fiktion og historisk fremstilling nedbrydes. Disse udfordringer af de generiske former i kunsten er synlige mere bredt, men i værker, der behandler historiske traumer, hæves den kulturelle indsats i disse brud på kanoniserede genrekonventioner.

Junot Díaz' roman The Brief Wondrous Life of Oscar Wao er et eksempel på dette. Romanen er en familiekrønike, der tager sit udgangspunkt i den unge nørdede og overvægtige Oscar, der bor i USA, drømmer om at blive science fiction-forfatter og lider under ikke at være en rigtig dominikansk mand med rytme, machismo og held med kvinder. Omkring Oscars historie udfoldes familiekrøniken domineret af generationers konflikter med det dominikanske diktatur; en familieforbandelse, der også bliver Oscars skæbne. Romanen beskæftiger sig med diktaturet, men ser det fra emigrantens perspektiv, fra en position nær ved og determineret af, men alligevel adskilt fra den Dominikanske Republiks kultur og historie. Romanen er således en roman om både immigration og identitetsdannelse på tværs af kulturer og traditioner og en traumatisk slægtshistorie, der nødvendigvis farver emigrantens perspektiv. Romanen forlader traditionelle modi for autentisk fremstilling af traumatisk historie og griber til højt tempo, geografiske skift, tosproget slang, eksplicitte fiktionalitetsmarkører, overnaturlige begivenheder og et omfattende reservoir af høj- og populærkulturelle referencer. Særligt benyttes science fictionreferencer til at fremstille både diktaturet, den magisk-realistiske tradition fra Mellemamerika og immigrantens erfaring af at stå imellem to uforenelige verdner. Med mange omfattende fodnoter efterligner romanen endvidere en videnskabelig ikke-fiktiv fremstillingsform. Denne undermineres dog af fodnoternes uvidenskabelige tone og af det forhold, at de henviser til både genre-litteratur og historiske begivenheder.

Romanens form rejser således spørgsmål om, hvordan denne sammenblanding af historiske og magiske begivenheder og forskellige fremstillingsformer fungerer, og om hvorvidt denne form overhovedet er etisk forsvarlig i forhold til det historiske stof. Denne artikels tese er, at romanens højlydte og hybride stil tjener til at modsvare diktaturets og dødens traumatiserede tavshed, og at en magisk realistisk tradition forbindes med vestlig historieskrivning og popkultur i et portræt af immigrantens hybride identitet. Jeg vil argumentere for, at værkets intertekstualitet, der eksempelvis sammenligner diktatoren Rafael Trujillo med Sauron fra Ringenes Herre, og dens eksplicitte fiktionalitet (de magiske begivenheder, fortællerens stereotype karakter, sci-fi-referencerne, fremstillingens farverigdom og endelig den veloplagte fremstilling af den stakkels Oscar som romanhelt og plottet som dannelseshistorie) udtrykker skepsis over for muligheden for en autentisk fremstilling af den historiske virkelighed og fungerer som "cifre", bag om hvilke den historiske realitet alligevel kan tilnærmes og forestilles.

Romanen efterlader ingen tvivl hos læseren om, at der er tale om et fiktivt værk. Men den insisterer samtidig på en nær relation til en historisk virkelighed, og læseren inviteres eksplicit til at udspørge og kritisere den fiktive fremstillings udsagn. Dermed rejser romanen spørgsmålet om, hvorvidt en traditionel opfattelse 
af fiktion som ikke-referentiel fortælling, dvs. som noget, der ikke refererer direkte til den eksterne virkelighed, men udelukkende til den virkelighed, som værket selv skaber (se f.eks. Cohn), er tilstrækkelig. Den værkeksterne virkelighed og historie er i højeste grad på spil i Oscar Wao, og midt i fordybelsen i det fiktive univers afkræves læseren en kritisk tilgang til selvsamme fiktive udsagn: Romanen lægger op til skeptisk refleksion over for værkets relation til historien, samtidig med at fiktionen inviterer til en suspension af selvsamme skepsis, når romanens magiske begivenheder i sidste ende får lov at stå til troende.

I The Rhetoric of Fictionality præsenterer Richard Walsh en alternativ model for fiktiv kommunikation, som er nyttig i forståelsen af Oscar Wao. Fiktionalitet er i denne model en kommunikativ ressource, der kan benyttes til at signalere (for så vidt som læseren i sin partikulære kontekst er indforstået med de sendte signaler), at det, der siges, skal opfattes som fiktion. Denne model åbner op for, at fiktionalitet også kan findes uden for generisk fiktion, ligesom den lægger op til, at faktiske sagsforhold, der inkluderes i det fiktive værk, kan bedømmes kritisk - som ikkefiktive udsagn, der finder sted inden for den fiktive rammesætning.

I Oscar Wao påkaldes en historisk kontekst, hvis historiske referentialitet er central for læsningen af værket - et forhold der dårligt er plads til inden for en traditionel forståelse af fiktion som en generisk størrelse. Fiktionaliteten vil i en sådan forståelse ofte afskære værket fra også at være et udsagn om virkeligheden. Men romanen fungerer netop i relation til en historisk kontekst, hvis faktiske eksistens er værkets præmis og motivation. Jeg vender tilbage til dette sidst i artiklen, men først vil jeg gennem en analyse af romanens brug af traditionelle strategier for autentisk repræsentation påvise, hvordan romanen på den ene side læner sig op ad velkendte repræsentationsformer, og på den anden rummer et alternativt bud på en sådan.

\section{Autenticitet}

Romanen trækker i udgangspunktet på tre traditionelle strategier for autentisk repræsentation, som den dog løbende kritiserer og dekonstruerer:

I) Repræsentationen af det autentiske objekt, hvor målsætningen er at fremstille fortiden "som den faktisk var" gennem en sober, kildekritisk form.

2) Repræsentationen af den autentiske erfaring, hvor forfatteren bærer vidne om en genuin erfaring og har privilegeret adgang til begivenhederne - ikke gennem fremstillingens indiskutable sandhedsværdi, men gennem forfatterens troværdige fremstilling af sin egen oplevelse af begivenhederne.

3) Repræsentationen af fortidens utilnærmelighed, hvor værket udtrykker en skepsis over for muligheden for autentisk repræsentation af fortiden og anser sig selv for nødvendigvis at være inautentisk. Her bliver stilhed eller hermetiske former til de eneste adækvate fremstillingsstrategier. 
Den første strategi kendes fra kildekritisk historieskrivning, mens de sidste to er kanoniseret $\mathrm{i}$ vidnesbyrdslitteratur og Holocaust-repræsentation.

Díaz trækker på disse traditionelle fremstillingsstrategier, men han problematiserer dem og spørger dermed til muligheden for overhovedet at nærme sig en autentisk repræsentationsmåde, samtidig med at romanens tone højlydt afviser stilheden som den eneste tilbageværende mulighed. Jeg vil i det følgende kigge nærmere på alle tre, som de forhandles i romanen. Derefter vil jeg foreslå en fjerde strategi (4), som jeg mener, karakteriserer romanen og dens dobbelte eksponering af fiktionalitet og autenticitet: Mellem historie og fiktion åbnes et rum for forestilling og fortolkning, der muliggør en tilnærmelse til de fortidige begivenheder - eller (med et begreb lånt fra Andreas Huyssen) "autentificering”.

\section{Historieskrivning og fortiden "som den faktisk var"}

Romanens plot drives fremad af en forbandelse - eller "fukú" - knyttet til Trujillos diktatur. ${ }^{.}$Romanen er, får vi at vide, en "fukú-story”, og vi følger Cabral-familien gennem tre generationers tragedie, vold og tab orkestreret af regimet. Diktatorens undertrykkende narrativ tvinger andre stemmer til tavshed ved at slå dem ihjel, ødelægge efterladte dokumenter eller ved at installere traumatiske tavsheder og selvvalgte hukommelsestab i overlevende ofre. At fortælle historien har til formål at virke imod forbandelsen og modsætte sig dens stilhed. ”My very own counterspell”, kalder fortælleren det (Díaz 7). Men Yunior, romanens fortæller, bliver hele tiden forhindret $\mathrm{i}$ sit forehavende, når han møder historiens hav af stilhed og "monumentale" tavsheder i hovedpersonerne: "We are trawling in silences here. Trujillo and Company didn't leave a paper trail - they didn't share their German contemporaries' lust for documentation. [...] And the remaining Cabrals ain't much help either [...] there is within the family a silence that stands monument to the generations, that sphinxes all attempts at narrative reconstruction" (Díaz 243). Yuniors opgave bliver at fortælle historien på trods af og hen over regimets, dødens og traumets tavshed. Han benytter den historiske viden, han har til rådighed, og fremstiller denne viden i en imitation af en kildekritisk historisk fremstillingsform gennem omfattende brug af lange fodnoter, der leverer baggrundsviden, historiske data, og (uspecifikke) referencer til dokumentation, fotografier og interviews. Den autoritet, der er knyttet til denne fremstillingsform, udfordres dog løbende. Yunior minder gentagne gange læseren om, hvor lidt han faktisk kender til de historiske omstændigheder, han blander sci-fi-referencer og kulørte beskrivelser ind i de historiske henvisninger, og han reflekterer endda over de æstetiske valg, der er truffet på bekostning af fortællingens sandhedsværdi, og kompromitterer dermed historieskrivningens troværdighed.

I Forbandelsen har dog en længere kulturhistorie i Latinamerika og går helt tilbage til opdagelsesrejserne og den tidlige kulturelle globalisering. Romanen trækker en linje fra opdagelsesrejsernes voldelige konsekvenser til de moderne diktaturer og den deraf følgende emigration. 
Yunior reagerer selv med rimelig skepsis på de overnaturlige begivenheder, han møder i sin research (blandt andet forbandelsen, en ildevarslende mand uden ansigt og et magisk guldøjet desmerdyr), og læseren inviteres eksplicit til at dele denne skepsis. Men skønt Yunior ikke tror på dem, favoriseres de overnaturlige forklaringer alligevel, og de har virkelig magt over plottets udvikling: "It's perfectly fine if you don't believe in these 'superstitions.' In fact, it's better than fine - it's perfect. Because no matter what you believe, fukú believes in you" (Díaz 5). Det magiske desmerdyr redder både Oscar og hans mor, Beli, og læseren forlader sig løbende på de konventioner, der er knyttet til de magiske elementer: Den oldgamle bedstemor beder - og vi ved, at redningen kommer. ("Let me tell you, True Believers: in the annals of Dominican piety there has never been prayer like this” Díaz I44). Den ildevarslende ansigtsløse mand dukker op i en gyngestol ved vejen - og vi ved, at forbandelsen snart slår til. Den historiske fremstillingsform benyttes til at underbygge den magiske fortælling på pseudovidenskabelig manér, og den virkelighed, der er romanens bagtæppe, og som præsenteres i fodnoterne, fremmedgøres og fortrylles på ny gennem romanens fiktionalisering. Vestlig skepsis og videnskabelig fremstilling er på den ene side gennemgående, mens magien på den anden side står til troende.

Ved at fremstille de historiske omstændigheder gennem en blanding af historiske fakta og magisk realisme skitseres kontrasten mellem de to tankesæt, der ligger bag Yuniors og Oscars position: Et vestligt, videnskabeligt tankesæt og et traditionelt, magisk, hvor forbandelsen hører hjemme. Begge verdenssyn holdes i luften og er centrale for den immigrantidentitet, som romanen udforsker. Forbandelsen er virkelig inden for det ene, og den styrer handlingen og motiverer fortællingen. Samtidig betvivles dette magiske verdensbillede gennem fortællerens skepsis og de videnskabelige forklaringer. To opfattelser af autenticitet er udstillet her: På den ene side det autentiske som den objektivt videnskabelige sandhed, på den anden side det autentiske som noget eksotisk og oprindeligt, noget vi længes mod, og som andre kulturer (måske) har. Blandingen af historisk information og eksotisk fascination er en central årsag til den læselyst, romanen inspirerer til. Samtidig understreger imitationen af historisk fremstilling og metode inden for fiktionens ramme, at både historiske og magiske logikker beskriver - og kommer til kort over for - samme virkelighed.

Fodnoterne leverer et historisk bagtæppe for fortællingen, og formens ironi og refleksivitet gør, at læseren føler tillid til fortællerens løst skitserede historiske viden og føler sig hjemme i hans kritiske refleksivitet. Romanen balancerer således hele tiden imellem en genkendelig, kritisk tænkemåde og en charmerende og eksotisk andethed. Begge tilsyneladende "autentiske". Ved endvidere at lade Oscars stemme klæde den mellemamerikanske magi i science fiction-referencer kommer romanen som sådan til at udgøre en fortsat udveksling ikke bare mellem de to kulturer, som både Oscar og Yunior balancerer imellem, men også mellem deres specifikke position og en global kultur, hvor referencerne er genkendelige.

Hvor en historisk kildekritisk fremstilling kun accepterer én autentisk virkelig- 
hed, tillader romanens fiktionalitet den dobbelte eksponering af flere autentiske virkelighedsopfattelser. Disse motioneres simultant, og således benytter romanen sig produktivt af historieskrivningens konventioner, mens kontrasten mellem science fiction og dokumentation bidrager til portrætteringen af immigrantens position på kanten af konventionelle opfattelser af, hvad den autentiske virkelighed består i.

\section{Vidnesbyrd og autobiografisk fremstilling}

Fortælleren er en stereotyp dominikansk macho-mand, og romanen cirkler om en kritik af denne type maskulinitet. Denne kritik udfoldes i relationen mellem fortæller og hovedperson, Yunior, den pralende "player", og den nørdede Oscar. I et centralt kapitel overlades fortællerstemmen til Oscars søster Lola (Lola er Yuniors kæreste $\mathrm{i}$ en periode og fungerer som bindeled mellem Yunior og Oscar), og hun får selv lov til at fortælle sin historie. Da læseren ved, at Yunior i skrivende stund kun har løs kontakt med Lola, må man dog betvivle, at stemmen i virkeligheden er hendes. Kan Yunior tale for hende, fordi han kender hende intimt? Det ukarakteristiske ved dette kapitels fortællerposition udgør under alle omstændigheder et brud, der gør det nødvendigt at spørge til, hvad der er på færde her. Bruddet synliggør Yuniors rolle som fortæller og tvinger læseren til at se med skepsis på den magt, han udøver over stemmer og personer: Yunior leverer løbende farverige og opfindsomme beskrivelser af begivenheder, som han indrømmer ikke at have et egentligt kendskab til og forskyder, ved at forskanse sig bag pseudovidenskabelige referencer og refleksioner over sin egen uvidenhed, ansvaret for disse påhit. Oscar står i modsætning til dette, i og med at hans naivitet og rendyrkede sci-fi-skriverier frasiger sig enhver bemestring af historien.

Yunior minder løbende læseren om, at han selv er involveret $\mathrm{i}$ begivenhederne og dermed om sin status som vidnebærer. Men hans vidnesbyrd er problematisk i den forstand, at han ikke bare bærer vidne om det, han selv kender til eller har erfaret, men fremstiller en hel familiesaga, som han nødvendigvis kun kender udefra og kun har begrænset adgang til. Forbandelsen, der bevidnes, hører ikke ham til, men han tillader sig alligevel at være den, der fortæller om den og giver den form. Denne magt over historien ligner diktatorens (Se f.eks. Jay 192-I93) og forbindes til den type maskulinitet, som både Yunior og Trujillo repræsenterer. Dette understreges igen af, at det er Lola, der får sin egen stemme, hun, der er den eneste, som i sidste ende formår at ryste Yuniors machismo.

Romanen inviterer dog til en refleksion over forfatterens position i denne sammenhæng. Yunior fremstilles som et stereotypt portræt af Junot Díaz selv, og denne antydede sammenhæng understreges af, at Yuniors diktatoriske maskulinitet forbindes til forfatterrollen: I en fodnote på side 97 lyder det: "Rushdie claims that tyrants and scribblers are natural antagonists, but I think that's too simple; it lets writers off pretty easy. Dictators, in my opinion, just know competition when they see it. Same with writers. Like, after all, recognizes like" (Díaz 97). Bærer Junot Díaz da vidne om en historie og en erfaring, som han har et vist ejerskab over? 
Et egentligt vidnesbyrd forudsætter, at et vidne træder frem som sig selv og bærer vidne om sine erfaringer, og er baseret på en juridisk fortolkningsramme, hvor det, der siges, bedømmes ud fra øvrigt bevismateriale om virkelige sagsforhold. Vidnesbyrdet kræver derfor en ikke-fiktiv rammesætning, som romanen naturligvis ikke leverer. Det autentiske forstået som den personlige erfaring af virkeligheden benyttes eksplicit i afsnittet om Lola, hvor hun selv træder ind og fortæller om sit liv. Men bruddet i fortællerpositionen synliggør Yuniors diktatoriske magt over historien, og således problematiseres også denne fremstillingsform. Yunior er en hybridfigur, der på den ene side trækker på forfatterens biografi og på den anden side fremstår som en inautentisk stereotyp. Således lægges fiktionalitet og historisk virkelighed igen ind over hinanden.

\section{Stilhed og gestik}

Stilhed er et gennemgående tema i romanen. Yuniors fortælling udfordres hele tiden af en voldsom og undertrykkende stilhed orkestreret af diktaturet. Denne stilhed bliver bragt ind i teksten, hvor Yunior hele tiden støder på "paginas blanco" i historiebøgerne, huller i dokumentationen og tavshed i personerne, der enten ikke formår eller ikke ønsker at tale. Han udfylder ofte disse stilheder med spekulative beretninger $\mathrm{i}$ et forsøg på at modsætte sig regimet og nægte det magten til at undertrykke andre fortællinger og stemmer. Dette indebærer dog, som vi har set, en magtudøvelse i sig selv.

Nogle gange er stilhederne monumenter, håndgribelige i deres egen ret, som end ikke den fantasifulde Yunior kan udfylde eller overdøve. Beli (Oscars mor) er for eksempel fuldkommen tavs omkring sin barndom:

"Of those nine year [...] Beli did not speak. [...] That entire chapter of her life got slopped into those containers which governments use to store nuclear waste, triple-sealed by industrial lasers and deposited in the dark unchartered trenches of her soul.” (Díaz 258)

Stilheden får sin egen form og geografi og bliver uomgængeligt tilstedeværende. Senere (i Belis liv, tidligere i fortællingens kronologi) bliver Beli næsten tævet ihjel og mister sit ufødte barn. ”About I67 points of damage in total," får vi at vide (Díaz I47). Yunior vælger at forbigå selve volden i tavshed og rapporterer i stedet på de fysiske skader, der kan vurderes efterfølgende. Tavsheden mellem den tomme reference til Oscars rollespil og den kontante rapport optegnes tydeligt og efterlader et rum til ubehagelige forestillinger om, hvad der kan være foregået:

"Was there time for a rape or two? I suspect there was, but we shall never know because it's not something she talked about. All there can be said is that it was the end of language, the end of hope. It was the sort of beating that breaks people, breaks them utterly.” (Díaz I47) 
For læseren er resultatet gribende og voldsomt. Stilheden stilles frem som en fysisk tilstedeværelse og peger på det, der findes i stilheden, på volden og smerten, der forbliver utilnærmelig for læseren.

Romanens organisering af sit stof $i$ en opbrudt kronologi tjener dog til at etablere Beli som noget ganske andet end et tavst offer i læserens bevidsthed. Hun er først og fremmest Oscars og Lolas dominerende mor og en højlydt latina. Før vi får adgang til hendes barndoms tragedier, får Yunior givet hende personlighed og stemme, og tilsammen skabes et farverigt portræt af et helt og flerfacetteret menneske. Spændingen mellem stilhed og støj, Belis larmende dominans og hendes traumatiske tavsheder, tjener til at nuancere portrættet af hende, som offer for en slægtsbestemt forbandelse, men også som medansvarlig aktør i sin egen skæbne. Denne spænding mellem stilhed og larm er gennemgående i romanen og tjener til på den ene side at markere stilhedens uomgængelighed, men også til at trodse den og stille levende, kulørt tale over for dødens og smertens tavshed.

Både Beli og Oscar reddes af det guldøjede magiske desmerdyr, efter at de næsten er blevet slået ihjel (det samme sted og af næsten samme årsag - forbandelsens magiske cirkelstruktur er som taget ud af García Márquez). ${ }^{2}$ Til Beli fortæller desmerdyret, hvad fremtiden vil bringe; flere børn. Og det giver hende kræfter til at kæmpe videre. Til Oscar siger den

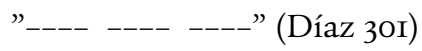

Her benyttes stilheden til at understrege talens gestus. Desmerdyret siger noget, og Oscar bliver reddet. Dette synes også at være Yuniors pointe og romanens formelle grundprincip: Talen er i sig selv det magiske ord, og talens gestus, selve den kommunikative handling er modbesværgelsen, der kan modsvare forbandelsens stilhed - skønt det at tale i sig selv er en magthandling og potentielt problematisk eller endog diktatorisk.

Stilhed er et virkemiddel i romanen så vel som dens udfordring: Historiens stilhed må ikke forblive tom, men må fyldes og overdøves med fortælling og tale. Samtidig er der begivenheder, som ikke kan beskrives, og dér er romanens smertepunkt: hvordan kan man både tale og ikke tale, fylde tavsheden og respektere den, fortælle historien uden at dominere den? Dette dilemma har heldigvis sin egen tradition fra den traumatiske erindringslitteratur. Repræsentationsproblemet er grundlæggende i kulturelle fremstillinger af krige og folkemord, og vidnesbyrdslitteraturen har som nævnt ovenfor leveret sine egne kanoniske former til at tackle dette problem. Som vi har set, forholder Oscar Wao sig til denne tradition og benytter nogle af dens

2 Se også Hanna 5oo: "The history [Yunior] relates is not one of linear progression like conventional representations of history. Rather, the history that he relates is cyclical. With echoes of Gabriel García Márques's Cien años de soledad, successive generations, each ignorant of the history of its ancestors, seem doomed to re-live the violence and evil wrought by the family curse." 
fremstillingsstrategier, men romanen problematiserer dem også og giver i sidste ende et alternativt bud, der er knyttet til værkets fiktionalitet.

Artiklens sidste del vil forsøge at indkredse denne repræsentationsmodus med udgangspunkt i to andre eksempler, der har gjort sig bemærket inden for Holocaustrepræsentationen.

\section{Autentificering}

Imre Kertész skriver i "Hvem tilhører Auschwitz?” om Roberto Benignis Livet er Smukt (I997), at "autenticiteten [skjuler] sig i detaljerne, men ikke nødvendigvis i genstandenes lighed med virkeligheden." (Io) Og senere: "Denne film er som et urgammelt koglespil, den berører os med eventyrets kraft." (Kertész' pointe er, at det netop er filmens eksplicitte fiktionalitet, der gør, at den undgår at blive kitsch, mens værker, der postulerer en autenticitet, samtidig med at de holder Holocaust "borte fra de menneskelige erfaringers verden" ved at fastholde de historiske begivenheders radikale utilnærmelighed, snarere er det. Det er fiktionalitetens invitation til læseren om at indleve sig i værdier og forhold uden for hans egen aktuelle virkelighed, der giver Livet er Smukt sit særlige potentiale i denne kontekst. Fiktionaliteten inviterer til at læseren indlejrer begivenhederne sin egen erfaringsverden.

Art Spiegelmans graphic novel Maus er et andet eksempel på dette. Værket er et eksempel på Holocaust-repræsentation, der med tegneseriegenrens popkulturelle tradition og repræsentationen af nazisterne som katte og jøderne som mus, også rejste spørgsmål om repræsentationsmådens etiske bæredygtighed. Maus omhandler Spiegelmans fars oplevelser under Anden Verdenskrig og i kz-lejrene. I et interview om Maus udtalte Spiegelman: "I'm bound to do something inauthentic. [...] To use these ciphers, the cats and mice, is actually a way to allow you past the cipher at the people who are experiencing it. So it's really a much more direct way of dealing with the material” (Huyssen I30). I sin læsning af Maus argumenterer Andreas Huyssen for, at dette konstituerer en særlig form for mimesis, der respekterer fortidens urepræsenterbare tavshed ved at være "the same but not quite", Angleichung snarere end lighed. "Maus acknowledges", skriver Huyssen, "the inescapable inauthenticity of Holocaust representations in the "realistic" mode, but it achieves a new and unique form of authentication and effect on the reader precisely by way of its complex layering of historical facts, their oral retelling [Maus viser Arts far, mens han fortæller historien], and their transformation to image-text." (I3I). Samspillet mellem de historiske forhold, en eksplicit refleksion over fortællerpositionen og en eksplicit fiktionalisering er, vil jeg mene, hvad Huyssen peger på her. Jeg vil argumentere for, at noget tilsvarende er på færde i Oscar Wao.

Romanen fungerer gennem en lignende "layering" af historiske begivenheder, deres selvrefleksive repræsentation og de hyperfiktive referencer - ikke "imagetekst", men "tekst-image". De gennemgående sammenligninger af Trujillo med mørke magter og onde skurke fra science fiction- og tegneserieuniverser inviterer - netop ved at være upræcise og forsimplende - læseren til at træde tættere på 
historien, til at nærme sig den ved selv at orientere sig i spændingsfeltet mellem historisk information og fantastisk ciffer. Romanens fiktionalitet fjerner altså ikke romanen fra den historiske virkelighed, men giver tværtimod læseren adgang til en autentisk relation til historien ved at lade læseren væve de historiske begivenheder og de menneskelige erfaringer, følelser og sanseoplevelser, der er knyttet til den, ind i sin egen erfaringsverden.

Romanen trækker på ikke-fiktive fremstillingsformer, vidnesbyrd og stilhed, men som disse strategier forhandles i romanens kulørte univers, bliver resultatet ikke autenticitet. I stedet tjener de til at markere tilstedeværelsen af en virkelig historisk kontekst og bringe dens utilnærmelighed og kompleksitet til stede i romanen som præmis og problem. Den dobbelte eksponering af historisk virkelighed med fiktionalitet og billed-cifre skaber et flerfacetteret blik på den virkelighed, der fremstilles. Oscars naive og nørdede blik på verden er de hyperfiktive referencers udgangspunkt, og cifrenes åbenhed knyttes til hans blidere maskulinitet som et mindre diktatorisk og mere uskyldigt udspil, der giver læseren rum til at forestille sig og nærme sig den historiske virkelighed, der er romanens omdrejningspunkt og ærinde. Mellem Oscar og den snævre historisk-videnskabelige form dannes et spændingsfelt, hvori virkeligheden må tilnærmes og reflekteres. Et eksempel er, hvad der skete med Beli: Det var hverken bare "I67 points of damage" eller summen af hendes fysiske skader. For den unge pige er det at blive tævet, voldtaget, at miste sit ufødte barn og sine fortænder en erfaring, der ikke kan beskrives af kølige rapporter eller inden for Oscars rollespilsvokabular.

Et andet eksempel: Oscars bedstefar, Abelard, blev ligesom Oscar dræbt af regimet. Det gjorde han, fordi han havde en smuk datter, som han gemte bort fra Trujillos sultne blik. Om denne historie (som netop er blevet fortalt med stor detaljerigdom, præcision og autoritet) skriver Yunior:

"Let's be honest. The rap about The Girl Trujillo Wanted is pretty common on the island. [...] So common that Mario Vargas Llosa didn't have to do much except open his mouth to sift it out of the air. [...] It's one of those easy stories because in essence it explains it all." (Díaz 244)

Han fortsætter derefter med at skitsere en alternativ historie, i hvilken Abelard skrev en mystisk bog om Trujillos overnaturlige evner, en bog, der var årsagen til hans arrestation og mordet på ham. "Mysterious books, a supernatural, or perhaps alien, dictator who had installed himself on the first Island of the New World and then cut it off from everything else, who could curse or destroy his enemies - that was some New Age Lovecraft shit" (Díaz 246). Ved at give denne hyperfiktive version af historien peger Díaz på, at den konventionelle og velkendte fortælling er for simpel. Den alternative forklaring peger på, at sandheden nogle gange ligner science fiction (øen er den første i Den Nye Verden, den blev afskåret fra omverdenen, og diktatoren kunne ødelægge sine fjender), og modstillingen af de to versioner af historien opfordrer læseren til at se nærmere på fortællingens nuancer: begge versioner er 
forsimplede, så hvad var der egentlig på færde? I den første udgave bliver Abelard en selvmodsigende endda utroværdig figur: han forekommer uforståeligt naiv over for regimet og Trujillo, og dette stemmer dårligt overens med hans intellektuelle engagement og den kløgt, han i øvrigt udviser. Science fiction-versionen kommer nærmest til at virke lige så overbevisende - med visse modifikationer naturligvis. Skrev Abelard alligevel et kritisk dokument, der omhandlede Trujillo? Det ville ikke passe dårligt til hans karakter i øvrigt. Gennem den science fiction-inspirerede fortælling inviteres læseren til at gå i dialog med historien og forholde sig til den bag om dens repræsentationer.

Sammenligningerne af Trujillo med Galactus, Sauron eller andre superskurke synes problematiske, idet de karikerende afdramatiserer Trujillos ondskab ved at placere ham i et univers, hvor godt og ondt er utvetydige og ukomplicerede størrelser. De fremstiller endvidere hans ondskab som radikal og ubegribelig inden for en traditionel historisk rammesætning. Men unuancerede som de er, inviterer sådanne referencer til, at læseren nuancerer dem og går bagom dem (ligesom man går bag om Spiegelmans katte og mus) til de følelser og de individuelle erfaringer, der ligger bag både fiktive sammenligninger og historiske fremstillinger. Der skabes plads til læserens egne kritiske vurderinger og følelsesmæssige engagement $\mathrm{i}$ de historiske begivenheder - til autentificering. Referencerne forbinder desuden romanen med et værkeksternt tekstkorpus og en bredere litteraturhistorie, der udgør et reservoir af fælles kulturel ballast for både Oscar, Yunior og læseren, og som udgør et potentielt mødested mellem en fælles global kultur og den partikulære historie.

Fortiden som autentisk objekt kan på grund af kulturel, geografisk eller tidsmæssig afstand ikke altid tilnærmes eller bevidnes. Men stilhed forekommer alligevel at være et utilfredsstillende alternativ. Jeg har argumenteret for, at Díaz' brug af historiske fremstillingsformer, vidnesbyrd, tavshed i mødet med fiktionalitet åbner op for et engagement $i$ historien, for tilnærmelse og autentificering. Et møde, der synliggøres ved en revideret forståelse af, hvad fiktion og fiktionalitet er.

Men vi engageres også - og det er måske ikke mindre vigtigt - $i$ fortiden gennem romanens kulørte form, fremstillingsmæssige overskud og de underholdende og farverige karakterer, der afføder begejstret og engageret læsning. Denne læselyst vokser ud af det hybride sprog, overskuddet af nørdede referencer og - ikke mindst - af mødet mellem det kendte og det eksotiske, to modsatrettede autentiske erfaringsverdner, der giver romanen en veloplagt tone knyttet til immigrantens hybride ståsted.

Samtidig er læseglæden og science fiction-referencernes underholdende udvej fra de traumatiske begivenheder potentielt problematiske. Gennem Oscars dannelseshistories usandsynlige forløsning og verdens genfortryllelse gennem det magiske blik fører romanens fiktionalitet og elegante narrative struktur til en nydelsesfuld læsning, der er i fare for at kamuflere snarere end at synliggøre de historiske smertepunkter. Balancen er her mellem muligheden for at bringe historien ind i læserens erfaringsverden og samtidig respektere det umulige i denne opgave. Ovenstående 
analyse søgte at demonstrere romanens forsøg på at opretholde denne balance og vise den måde, hvorpå repræsentationens problemer er tematiseret og fortællingens potentielt diktatoriske magt kritiseret.

Romanen eksemplificerer en aktuel tendens inden for erindringslitteratur og forskning i kulturel erindring, der undersøger senere generationers og emigranters omgang med historiske traumer og dermed muligheden for at indlemme historiske begivenheder i vores levende erfaringsverden. Maus og Livet er Smukt kan ses som tidlige eksempler på denne tendens, men værker som Ari Folmans film Walz with Bashir (2009), Neill Blomkamps District 9 (2009), Marianne Satrapis graphic novel/ tegnefilm Persepolis (2000/2007), Jonathan Littells De Velvillige (2006) og Jonathan Safran Foers Tree of Codes (20IO) er vidt forskellige og på ingen måde enestående eksempler på aktuelle repræsentationer af historiske traumer. Alle disse værker forlader sig på den ene side på (nogle af) ovennævnte traditionelle repræsentationsmodi, men Littells knap tusind siders fordybelse i en sadistisk forbryder, District 9s sci-fi-dokumentariske fortolkning af apartheid og tegnefilm og -seriemediernes ikoniske repræsentationer ombryder og udspørger blandt andet gennem deres brug af fiktionalitet det dokumentariske, det autentiske og det sobert realistiske, som de skriver sig op imod. I Junot Díaz' The Brief Wondrous Life of Oscar Wao kommer emigrantens ståsted, adskilt både i tid og rum fra den dominikanske historie og i en position af sprogligt og identitetsmæssigt overskud, til at danne udgangspunktet for et højlydt modsvar til traumets nedbrydning af identitet og sprog.

\section{LITTERATURLISTE}

Benigni, Roberto. Livet er Smukt. Cecchi Gori Group Tiger Cinematografica.Melampo Cinematografica. Cecchi Gori Pictures, I999.

Cohn, Dorrit. The Distinction of Fiction. Baltimore and London: The Johns Hopkins University Press, I999.

Díaz, Junot. The Brief Wondrous Life of Oscar Wao. London: Faber and Faber, 2008.

Hanna, Monica. "Reassembling the Fragments: Battling historiographies, Caribbean Discourse, and Nerd Genres in Junot Díaz' The Brief Wondrous Life of Oscar Wao". Callaloo 33/ı, 2010.

Huyssen, Andreas. "Of Mice and Mimesis: Reading Spiegelman with Adorno". Present Pasts - Urban Palimpsests and the Politics of Memory. Stanford: Stanford University Press, 2003.

Jay, Paul. Global Matters - The Transnational Turn in Literary Studies. New York: Cornell University Press, 20IO.

Kertész, Imre. "Hvem tilhører Auschwitz?". Passage 582007.

Langer, Lawrence L. Admitting the Holocaust. Cary: Oxford University Press, I996.

Spiegelman, Art. Maus. London: Penguin Books, 2003.

Walsh, Richard. The Rhetoric of Fictionality. Columbus: Ohio State University Press, 2007. 